\title{
Psycholinguistic Concept and the Model of Speech Influence by A.A. Leontiev and its Importance for Actualization of the Modern Communication Problems
}

\section{Психолінгвістична концепція і модель мовленнєвого впливу О.О. Леонтьєва та ї̈ значення для актуалізації сучасних проблем спілкування}

\author{
Ksenia Maksymenko ${ }^{1}$ \\ Dr. in Psychology, \\ Professor
}

Ксенія Максименко ${ }^{1}$

доктор психологічних наук, професор

E-mail: ksenia.maximenko@gmail.com orcid.org/0000-0002-6102-2479

\section{Heorhii Kalmykov ${ }^{2}$}

Ph.D. in Pedagogy, Assistant

Professor, Postdoctoral student
Георгій Калмиков ${ }^{2}$ кандидат педагогічних наук, доцент, докторант

E-mail: kalmykov_gv@ukr.net orcid.org/0000-0002-1378-5236

${ }^{1}$ National Academy of the Internal Affairs of Ukraine

1, Solomyanska Str., Kyiv, Ukraine

${ }^{2}$ SHEE «Donbass state pedagogical university» $\triangle 19$, General Batiuk Str., Sloviansk, Donbass Reg., Ukraine, 84100
${ }^{1}$ Національна академія внутрішніх справ Украӥни вул. Солом'янська площа, 1 , м. Київ, Україна

2 ДВНЗ «Донбаський державний педагогічний університет»

$\triangle$ вул. Генерала Батюка, 19, м. Слов'янськ, Донецька обл., Україна, 84100

Original manuscript received December 25, 2017 Revised manuscript accepted September 01, 2018 


\section{ABSTRACT}

The article reveals the main provisions of the concept of speech influence and describes its theoretical model, which was developed by well-known psycholinguist of the 20th century A.A. Leontiev. The main ideas of this concept are explicated within the scope of the problem of speech communication and conditioned by this verbal act processes of speaking of the communicator (speaker) and listening of the recipient (s). The speech influence is considered by the researcher of this problem at the level of the internal and external stages of the communicative-speech processes generation of the speaker and the recipient. That is why A.A. Leontiev pays great attention in this concept to the analysis of such psycholinguistic phenomena as: "value», "sense», "semantic field of the recipient», "sign", "internal speech", "internal programming", "act of speaking» etc. The article reveals the following aspects: a) established by A.A. Leontiev evolution of the forms of communication and its psychological and semiotic mediation; b) separated by him stages of the historical formation of the activity of communication, in particular its final stage - the speech effect, which becomes a professional activity, motivated "from inside the self»; c) distinguished by the researcher notions of "speech" and "speech activity", d) defined by him the notion of "communication" and its varieties, e) associated with orientation - the criterion of speech communication - speech effect, which is characterized as one of the aspects of psychological content of communication, f) identified by three parameters phenomenon of the sign and applied in its interpretation two methods of scientific analysis important for a deep understanding of speech influence used, through the processes of understanding (the transition from a sign to the thought) and through the objectification of the subjective communicative intention (the transition from a thought to the sign) and other important provisions of the proposed concept. The content of this manuscript also describes the psycholinguistic model of speech effect, which, according to the author, has statuses or psychological actions, or appears as an independent activity with its own motive, has a feedback, acts in various forms of interference with consciousness and subconscious of the personality, etc.; the ways of achieving changes in the recipient's existing values under the influence of the content of communicator's speech are represented; the threelayer psycholinguistic structure of the speech influence is substantiated. In the debating section of the article, it is suggested to consider the scientific work of A.A. Leontiev concerning the speech influence as a psycholinguistic theory, by taking into account its theoretical and practical significance for modern science and communicative practice.

Key words: speech influence; value; sense; semantic field of the recipient; sign; field of values. 


\section{Вступ}

У бурхливому інформаційному потоці сьогодення стрімко зростає науковий інтерес психолінгвістів до проблеми масової та міжособистісної комунікації, а також пов'язаного 3 нею питанняпсихологічного впливу на респондентів в акті мовленнєвої взаємодії.

На початку XXI століття, що характеризується складними й неоднозначними трансформаціями, які здійснюються в загостреному (біфуркаційному) режимі, наявна велика кількість досліджень, присвячених психологічному впливові (Доценко, 1996; Кабаченко, 2000; Ковалев, 1991; Латинов, 2012; Чалдини, 2010; Bessiere et al., 2008; Kraut et al., 2002; Raven, 1992; Shwarzer \& Knoll, 2007; Seidman et al., 2006; ValKenburg \& Peter, 2009; Wood, 2000; Gross, 2004 та багато ін.), проте проблематика мовленнєвого спілкування, в процесі якого й відбувається мовленнєвий вплив, до цього часу залишається недостатньо дослідженою.

Мовленнєве спілкування, спрямоване на той чи інший заздалегідь спланований ефект з огляду на його цілеспрямованість може бути експлікованим, вважає О.О. Леонтьєв, як «мовленнєвий вплив». Уперше це поняття було введено ним у науковий обіг у 1972 році й оприлюднене в матеріалах IV Всесоюзного симпозіуму 3 психолінгвістики й теорії комунікації, в статті «До психології мовленнєвого впливу» (Леонтьев, 1972). В ній презентовано психолінгвістичну концепцію та модель мовленнєвого впливу стосовно до феномену мовленнєвого спілкування. Ця його одноіменна маловідома сучасним дослідникам наукова праця була перекладена в той час на англійську, німецьку й чеську мови. Сам Олексій Олексійович схарактеризував суть цієї роботи досить скромно: «...побудувати найбільш загальну теоретичну модель» мовленнєвого впливу, на тлі якої можна було б у подальшому «... здійснювати експериментальні дослідження та створювати практичні рекомендації в галузі міжособистісної й масової комунікації» (Леонтьев, 1999: 281).

Тільки однією зазначеною вище науковою роботою 3 питань мовленнєвого впливу О.О. Леонтьєв не обмежився. В подальшому ця проблематика була розвинена в багатьох його фундаментальних психолінгвістичних публікаціях, присвячених мовленнєвому спілкуванню і мовленнєвій діяльності (Леонтьев, 1974, 1999, 2003). 
Проте, незважаючи на неоцінену до цього часу достатньо велику теоретичну й практичну значущість наукового доробку О.О. Леонтьєва щодо мовленнєвого спілкування, сучасні дослідники, як i їхні попередники, торкаються в своїх розвідках лише комунікативного аспекту цієї проблеми, не розмежовуючи феномени мовленнєвого спілкування і мовленнєвої комунікації (Вовк, 2014; Лахтадир, 2017; Немеш, 2017; Rabab'ah, 2016; Bosco \& Cabbatore, 2016). Варті особливої уваги небагаточисельні психолінгвістичні розвідки (Тарасов, 2010, 2017; Tavakoli \& Davoudi, 2017), які виконані саме в руслі мовленнєвого спілкування. Проте такий найважливіший аспект цієї проблематики, як мовленнєвий вплив (більшою мірою аналізується дискурсивний вплив) залишається, на жаль, поза увагою психолінгвістів, а відтак не удосконалюються відповідні йому (впливові) соціальні сфери суспільного життя, не гармонізуються взаємини суб'єктів спілкування. Саме тому вбачаємо за необхідне актуалізувати перспективні наукові положення цього вченого щодо мовленнєвого спілкування i детермінованого його історичним розвитком мовленнєвого впливу.

Meта cтатmі: розкрити суть розроблених О.О. Леонтьєвим теоретичних i прикладних психолінгвістичних положень щодо мовленнєвого впливу, показати, в якому напрямку розвивалися його погляди на цю проблему, як вони доповнювалися в змістовному плані, яке значення вони мають для фахівців, які реалізують себе в соціономічних (мовленнєво-орієнтованих) професіях.

\section{Методи та методики дослідження}

Використовувалися такі теоретичні методи, як: аналіз наукового доробку О.О. Леонтьєва, узагальнення психолінгвістичних положень щодо мовленнєвого впливу 3 його теорії спілкування, виокремлення основних понять та їх визначень, на яких грунтується уявлення науковця про вплив, ієрархізація й систематизація основних положень концепції мовленнєвого впливу, метааналіз його психолінгвістичної моделі, висновування тощо.

Емпіричні методи дослідження спрямовано на з'ясування можливостей використання й реального впровадження розроблених О.О. Леонтьєвим концепції i моделі мовленнєвого впливу в прикладних галузях психолінгвістики та існуючій практиці мовленнєвого спілкування в різних соціальних сферах. 3 цією 
Psycholinguistic Concept and the Model of Speech Influence...

метою запроваджено спостереження за мовленнєвою діяльністю психотерапевтів i психоконсультантів та інших фахівців соціономічних професій, лінгвістичний аналіз висловлювань, професійно спрямованих на вплив, дискурс-аналіз, контент-аналіз.

\section{Результати дослідження}

«Мовленнєвий вплив» як психологічна i психолінгвістична категорія представлена О.О. Леонтьєвим науковій громадськості теоретичними положеннями теорії мовленнєвого спілкування, в якій розкрита еволюція форм спілкування та його психологічна й семантична опосередкованість. Виокремлюючи кілька етапів в психологічній еволюції спілкування, він зазначає, що історичний розвиток його форм відбувається в таких векторах: «...від спілкування, включеного в якусь іншу діяльність, до спілкування як діяльності, до діяльності спілкування» (Леонтьев, 1999: 45-46). Серед етапів становлення діяльності спілкування виділяє особливий період, зумовлений соціально-економічним (а відтак - політичним) розвитком суспільства, що веде до подальшого розподілу праці i до появи специфічних вимог стосовно мовленнєвого впливу, який стає «спеціалізованою, нерідко професійною діяльністю», що закономірно спричиняє актуалізацію «повністю психологічно самостійної діяльності спілкування, мотивованої, так би мовити, зсередини себе. Така діяльність професійного оратора, лектора, драматичного актора... тощо» (Там само: 55-56).

У зв'язку 3 цим О.О. Леонтьєв 3 науковою доцільністю надає різний понятійний зміст термінам «мовлення» і «мовленнєва діяльність». Мовлення розглядає як потенційний компонент будь-якої діяльності, зокрема пізнавальної, мнемічної та ін., а мовленнєву діяльність - як спеціалізоване використання мовлення для спілкування, тобто окремий випадок діяльності спілкування, що передбачає мовленнєвий вплив. Останній визначає як різновид психологічного впливу, який будучи процесом, а не функцією «... здійснюється для чогось іншого, спрямовується й зумовлюється чимось» (Леонтьев, 1999: 61). Відразу слід зазначити, що в сучасній психології ці терміни здебільшого використовуються як синоніми, не зважаючи на їх різне лінгвістичне й психологічне значення. Отже, для О.О. Леонтьєва спілкування є процесом встановлення і підтримки цілеспрямованого, безпосереднього або 
опосередкованого тими чи тими засобами контакту між людьми, так чи інакше зв'язаними між собою в психологічному сенсі. Здійснення цього контакту дозволяє, по-перше, змінити перебіг колективної діяльності за рахунок узгодження діяльностей окремих індивідів за тими чи іншими параметрами або, навпаки, розподілу функцій, що характерно для соціально орієнтованого спілкування; по-друге здійснювати цілеспрямований вплив на формування й зміну окремої особистості або безпосередньо на іiі поведінку в процесі спільної або індивідуальної, але соціально опосередкованої діяльності, що притаманно особистісно орієнтованому спілкуванню. Таким чином, мовленнєвий вплив він пов'язує з таким критерієм мовленнєвого спілкування (коли воно є самостійною діяльністю та має «теоретичний» характер) як орієнтація (особистісно орієнтоване й соціально орієнтоване спілкування). Обсяг і якісна специфіка мовленнєвого впливу може, згідно з О.О. Леонтьєвим, визначатися як «ззовні» суспільством, так і «з середини» самою особистістю.

Розглядаючи мовленнєвий вплив у контексті діяльності мовленнєвого спілкування, О.О. Леонтьєв звертається до поняття «психологічна динаміка спілкування» й характеризує вплив як один 3 аспектів психологічного змісту спілкування. На його переконання мовленнєвий вплив може здійснюватися в сфері знань (інформування, навчання), в процесі формування умінь, навичок, під час власне діяльності в їі реальному здійсненні (навіювання, переконання), в галузі мотивів i потреб, настанов, ціннісної орієнтацій (переконання) тощо. У зв’язку з цим О.О. Леонтьєв додає думку про те, що мовленнєвий вплив, незалежно від того, чи він є публічним, «ораторським» мовленням, чи міжособистісним спілкуванням, не має «односпрямованого» характеру, тому має місце широкий спектр різноманітних змін у психічних станах i протіканні психічних процесів як у комунікатора, так і реципієнта (-ів), пов’язаних з процесами особистісно й соціально орієнтованого спілкування. Ці зміни, особливо стосовно реципієнтів, як зауважує дослідник, значною мірою прогнозуються комунікатором, проте далеко не повністю, оскільки моделювання мовцем особистості співбесідника, або психологічних характеристик аудиторії, ніколи не буває стовідсотково правильним і лише наближається до психічної реальності слухачів, адже завжди залишаються невідомими мовцеві 
відомості про реципієнтів, зокрема про їхні мотиви, настановлення, які не можуть бути використані в процесі такого моделювання.

Мовленнєвий вплив, що безпосередньо корелює 3 такими характеристиками як орієнтація й психологічна динаміка спілкування, О.О. Леонтьєв співвідносить 3 першою 3 трьох основних фаз мовленнєвої діяльності - фазою орієнтування й планування. Ці характеристики мовленнєвого впливу він пов'язує в основному 3 орієнтуванням мовця (комунікатора) в ситуації спілкування та мотиваційними й цільовими установками мовлення; координату психологічної динаміки мовленнєвого спілкування особливо тісно - 3 його діяльнісним характером. Цей взаємозв'язок обгрунтовує тим, що якісний розвиток в психологічній динаміці спілкування безпосередньо детермінований специфікою діяльності, в яку це спілкування включено та якій підпорядковане. Крім того, динаміка процесів, які відбуваються в системі спілкування, значною мірою, як зауважує дослідник цієї проблематики, спрямовується тим, наскільки мотив діяльності спілкування співпадає з їі результатом.

Однією 3 координат мовленнєвого спілкування О.О. Леонтьєв називає семіотичну спеціалізащію спілкування і 3 iï урахуванням тлумачить мовленнєвий вплив, використовуючи поняття: «знак», «значення», «смислове поле реципієнта», «смисл». Мовленнєвий вплив розглядає як такий, що передбачає спрямовані зміни в смисловому полі реципієнта за допомогою найбільш розповсюдженого шляху через значення: добору слів, словосполучень та організації їх у висловлювання на різних рівнях таким чином, щоб при сприйманні мовлення реципієнтом здійснилися бажані трансформації в його смисловому полі. При цьому, наголошує науковець, не відбувається безпосереднього впливу на особистісний смисл; він (мовленнєвий вплив) опосередкований сприйняттям знакових засобів, значення яких входить як необхідний i як основний компонент у зміст впливу. Семіотичну спеціалізацію та ступінь опосередкованості О.О. Леонтьєв співвідносить 3 другою фазою діяльності мовленнєвого спілкування - фазою реалізації іiі плану. Знакове спілкування, мову - вербальний знак мовленнєвого впливу, розглядає як найбільш розвинену, найбільш спеціалізовану діяльність за своїми соціально-психологічними функціями (Леонтьев, 1999). 
У розумінні поняття «знак» О.О. Леонтьєв спирається на його тлумачення, здійснене Е.В. Ільєнковим, і уявляє знак як квазіоб'єкт у його відношенні до реального об'єкта, як його замінник у певних ситуаціях діяльності. Стверджує, що мова $\epsilon$ саме такою системою квазіоб'єктів, де на місце реальних відношень підставлена їх наявна видима форма: «те, що дане нашій свідомості, ні в якій мірі не вичерпує суті справи» (Леонтьев, 1999: 98). Одночасно автор аналізованої концепції попереджає, що певну складність становить «... той факт, що під однією й тією ж назвою «знака» в практиці наукового дослідження виступають три різних аспекти, по суті, три не співпадаючих поняття» (Леонтьєв, 1999: 99-100). Вони, здебільшого, або нечітко розмежовуються, або взагалі не розмежовуються, хоча в психолінгвістичних і психологічних цілях розподіл їх виключно важливий. Отже, по-перше, знак - це реальний компонент об'єктивної дійсності, річ або матеріальне мовне «тіло», включене в діяльність людини; по-друге, знак - ідеальний образ, еквівалент «реального знака» в щоденній свідомості. Цей внутрішній образ він розуміє у відомому, але обмеженому, сенсі як внутрішню модель, що програмує діяльність суб'єкта завдяки тому, що вона відповідним чином моделює зовнішній світ. Для вербальних знаків, зауважує автор концепції, виокремлення цього аспекту особливо суттєво у зв'язку 3 поняттям «значення»; потретє, знак - продукт наукового осмислення структури і функцій об'єктивного знака, тобто знакова модель (Там само: 100).

Для суб'єкта психічної діяльності О.О. Леонтьєв представляє знак у двох іпостасях, як елемент двох різних проблемних ситуацій. 3 одного боку знак - суб'єктивний замінник дійсності - $є$ тим, що виступає перед окремою людиною як «носій» реальних ознак відповідного предмета або явища, як трансформована форма об'єктивно існуючих зв'язків і відношень, у які цей предмет вступає в процесі діяльності. Відтак перед суб'єктом стоїть завдання повернути квазіоб'єкт у світ реальних об'єктів. Об'єктивно знак передує суб'єкту як реальний знак, тобто знак 1 . Проте суб'єктивно він (суб'єкт) має справу з таким буттям знака як квазіоб'єкта, в якому реальне соціальне значення знака ніби зміщено і видозмінено в знак С. Свідомість індивіда залишається споглядальною: він лише «перекладає» знак на «мову» свого реального життя, але не спроможний вийти за межі свого уявлення про нього. 
3 іншого боку, як переконливо доводить автор концепції, знак використовується суб'єктом у якості того, що опосередковує комунікативний намір суб'єкта. В цьому випадку співвідношення знака ${ }_{1}$ і знака ${ }_{2}$, за його висновком, ніби перевернуто, оскільки в комунікатора кінцева мета - створення у реципієнта знака 2 , тому він має об'єктивувати відповідний зміст у знакові Саме тому всю психолінгвістичну проблематику мовленнєвого впливу О.О. Леонтьєв зводить до динаміки співвідношення суспільно-трудової діяльності реципієнта, передуючих йому квазіоб'єктів і суб'єктивних образів його свідомості, які відображають ці квазіоб'єкти.

Таким чином, при інтерпретації сутності знака О.О. Леонтьєв застосовує два шляхи аналізу, важливі для психолінгвістично коректного розуміння мовленнєвого впливу. Перший 3 них передбачає можливість відштовхуватися від властивостей реальних об’єктів, які використовуються в діяльності як функціональні характеристики знака, розглядати готовий знак і співвідносити його 3 предметною й суспільною дійсністю та 3 предметною діяльністю людини в ній. У такий спосіб аналізується знак через процеси розуміння: перехід від об'єктивного до суб'єктивного, від знака до думки. Другий шлях аналізу передбачає прослідковування того, як людина «втілює» в знак своє сприйняття й осмислення дійсності, як вона використовує знак для того, аби передати іншій людині певний психосемантичний зміст. У такому випадку знак аналізується через об'єктивацію суб'єктивного комунікативного наміру в знакові, через перехід від думки до знака. В обох випадках, зазначає О.О. Леонтьєв, маємо справу з проблемою значення і смислу. Проте, як він зауважує, слід визнати однобічним і абсолютно недостатнім зводити психолінгвістичну суть значення лише до того його аспекту, який зазвичай називають «предметною співвіднесеністю» або «предметним змістом». Таке розуміння, на думку дослідникааналітика, впирається в помилкове переконання, що об'єктивне лише те й настільки, що й наскільки безпосередньо співвіднесене зі світом речей, що знаходиться поза людиною. Відтак, на його погляд, єдино правильне розуміння природи значення таке, яке пов'язує значення зі змістом і структурою діяльності носіїв мови за умови, що власне ця діяльність буде розумітися як суспільна за своєю природою, а не тільки за своєю зовнішньою зумовленістю. Адже пізнання світу не є пасивним його відображенням. Воно за 
своїм походженням, акцентує увагу вчений, активне й пов'язане 3 суспільною практикою людини. Тому навряд чи доцільно говорити, що «мова моделює реальний світ». Доречніше було б сказати, що в мові, або, точніше, в мовленнєвій діяльності (мовленнєвому впливові) моделюється система відношень суспільної людини до світу. Значення не $є$ відображення денотата в дзеркалі мови. В психолінгвістичному аспекті значення - «система констант мовленнєвої діяльності», які зумовлюють відносну постійність іiі відношення до того чи іншого класу предметів або явищ дійсності відношення, що зумовлені суспільно практичним досвідом людства» (Леонтьев, 1999: 105).

Важливим аспектом у розробці О.О. Леонтьєвим проблеми мовленнєвого впливу $є$ розмежування ним понять «внутрішнє мовлення» i «внутрішнє програмування». Внутрішнє мовлення, як він обгрунтовано стверджує, «... $\epsilon-$ в загальному випадку - ні що інше, як використання комунікативних структур для когнітивних цілей; у цьому його найважливіша відмінність від внутрішнього програмування, яке становить собою у функціональному плані зворотне явище - використання когнітивних структур для комунікативних цілей» (Леонтьев, 1999: 110) з метою мовленнєвого впливу. Одночасно дослідник застерігає: якщо у внутрішньому програмуванні мовлення більш-менш безпосередньо відображаються й використовуються результати пізнавальної діяльності, то у формально-мовній структурі висловлювання (впливу) ні ці результати, ні тим більше сама когнітивна діяльність уже не відображені безпосередньо. Коли мовець у процесі впливу має справу iз застиглими у вигляді схем, образів, систем, правил, когнітивними й комунікативними структурами, продовжує думку вчений, тоді він діє 3 «квазіоб'єктами вищих рівнів або порядків» (Там само: 110). В мовленнєвому впливові - типовому інтелектуальному акті, який має трьохфазову структуру, є фаза орієнтування і планування, фаза здійснення і фаза контролю. Мовлення, за О.О. Леонтьєвим, наявне в цьому акті на всіх означених фазах. Мовленнєвим є планування дій 3 впливу і орієнтація в ситуації взаємодії 3 його адресатами. В такому випадку власне дії, що плануються є мовленнєвими, хоча в окремих видах інтелектуального акту вони можуть бути i не мовленнєвими. Характер планування мовленнєвих і не мовленнєвих дій не тотожний. У першому випадку - це програмування 
мовленнєвого висловлювання без попереднього формулювання плану за допомогою мови; в другому, - це власне формулювання плану дій у мовленнєвій формі, зазвичай в «умі». Між першим і другим інтегрально зв'язаним інтелектуальним процесом існує, попереджає вчений, величезна психологічна різниця, i лише існування розповсюдженого терміна «внутрішнє мовлення», яке покриває обидві фази латентно-довербального процесу, може певною мірою виправдати їх змішування більшістю психологів, які пишуть про мовлення (Леонтьев, 1999: 116-117). Вчений пропонує послідовно протиставляти в цьому розумінні «внутрішне програмування (характерне для мовленнєвого впливу) i «внутрішнє мовлення», а також вводити й використовувати поняття «внутрішнього промовляння», коли внутрішнє мовлення наближене до зовнішнього не тільки за функцією, а й за характером здійснення. Використання мовлення для орієнтування відповідає першим етапам мисленнєвого акту. Планування не мовленнєвих дій за допомогою мовлення відповідає підсумковому, основному етапу цього акту - власне вирішенню задачі. Коли дії є мовленнєвими, вони виходять за межі мисленнєвого акту як такого. Етап внутрішнього мовленнємислення завершився, рішення прийняте, пише О.О. Леонтьєв, вибір зроблено, залишається здійснити це рішення. Насамкінець, мовленнєвими $є$ не тільки дії й планування а й співставлення отриманого результату 3 наміченою метою. Ця рефлексія відбувається, коли інтелектуальний акт, зокрема мовленнєвий вплив, достатньо складний, особливо в частково теоретичній i теоретичній діяльності. Таким чином, не допускаючи спрощення реального співвідношення процесу мислення i процесу мовленнєвого спілкування (мовленнєвого впливу) О.О. Леонтьєв формулює: «мовлення не $є$ простою вербалізацією, підшукуванням і наклеюванням словесних ярликів до мисленнєвих сутностей: це творча інтелектуальна діяльність, включена в загальну систему психічної й іншої діяльності людини. Це - вирішення задачі, це дія в проблемній ситуації, яка може здійснюватися із опорою на мову» (Леонтьев, 1999: 118). Він застерігає, що принципово неправильний будь-який підхід, яким не враховується, що за терміном мислення стоять психологічно дуже різні явища, підхід при якому «... наукове витлумачення сутності мислення підмінюється спрощеним i схематизованим, можна сказати - формалістичним, його зображенням, як свого роду 
ланцюга логічних операцій - аналіз + синтез, індукція + дедукція і так далі, що здійснюються обов'язково на базі мови і в процесі мовлення» (Там само).

Розкриваючи когнітивний аспект мови, яка, згідно 3 його розумінням, є засобом розпредмечення об’єктивної дійсності, найважливішим знаряддям соціалізації особистості, О.О. Леонтьєв тим самим підкреслює особистісно-розвивальну роль мовленнєвого впливу на комунікантів, значення квазіоб'єкта вищого рівня комунікативних структур у вигляді системи метамовних правил.

Феномен мовленнєвого впливу О.О. Леонтьєв розкриває, як зазначалося, через поняття «значення» і «смисл» та їхні відмінності. Значення він розглядає як соціально кодифіковану форму суспільного досвіду. Ця кодифікованість $є$ його базовою ознакою й пов'язана з потенційною можливістю усвідомлення. Незважаючи на те, що значення об'єктивне, для кожного індивіда воно ніколи не виступає як об'єктивне явище. Це пов'язане 3 тим, що, засвоюючи суспільний досвід, зафіксований у значеннях, людина включає його в систему своїх життєвих відношень, у систему своєї діяльності. Будь-який зміст, закріплений у значенні, сприймається й переживається індивідом по-різному, залежно від мотиву відповідної діяльності. У зв'язку з цим обгрунтуванням учений говорить про смисл як про аналог значення в конкретній діяльності особистості. В об'єктивному значенні денотата слова і його смислу завжди певною мірою, наголошує О.О. Леонтьєв, є розбіжності, оскільки існують відмінності між «особистим» інтересом, «особистим» мотивом й інтересом суспільства в цілому. Смисл, здебільшого, поєднаний тим чи іншим способом 3 соціальною структурою суспільства. Тому смисл не індивідуальний, адже не індивідуальні мотиви діяльності людей, не індивідуальне відношення їх до предметної й суспільної дійсності, яке завжди зафарбоване тими чи іншими груповими інтересами. Ось чому смисл і значення вчений тлумачить як форму впливу суспільства на окремого індивіда, як форму суспільного досвіду, що засвоюється ним. Проте на відміну від значення, смисл - це не кодифікована форма. Здебільшого, смисл, за О.О. Леонтьєвим, не існує для людини-носія цього смислу як щось окреме від значення. Їй здається, що вона безпосередньо сприймає денотат в його об'єктивному значенні. Але слова сприймаються кожним з носіїв ніби через призму «особистісного», 
a не суспільного інтересу. Потрібне спеціальне зусилля думки, висновує науковець, аби піднятися над цим інтересом i вловити окремість смислу й значення.

Надаючи особливої уваги внутрішній соціальній зумовленості мовлення, вчений актуалізує важливий аспект, який, як правило, упускається дослідниками: «аналізується виключно розвиток і зміна значень, але ніколи особистісних смислів. Між тим, саме система смислів є основним каналом соціальної зумовленості мовленнєвої (й іншої) діяльності» (Леонтьев, 1999: 174). Саме психолінгвістичний аспект особистісних смислів він виокремлює, розкриваючи функції мовленнєвого спілкування, зокрема функцію соціалізації особистості через мовленнєвий вплив на вже сформовану особистість, що спрямований на зміну рівня знань, умінь, цінностей тощо. Це виформовування особистісних смислів засобами мовних значень; процеси смислоутворення через вербальний вплив.

Згідно із запропонованою О.О. Леонтьєвим психолінгвістичною моделлю (Леонтьев, 1999: 271-281) мовленнєвий вплив:

- має статус психологічної дії; він найчастіше є частиною більш складної діяльності, засобом досягнення певного позамовного завдання. У виняткових випадках мовленнєвий вплив постає як самостійна діяльність $з$ власним мотивом;

- у більшості випадків не залишається без зворотного зв'язку, мовленнєва комунікація суб'єкта впливу не є однобічною, учасники бесіди впливають один на одного. В умовах масової комунікації, ораторського мовлення здійснюється своєрідний зворотний зв'язок або враховується така потенційна можливість;

- існує кілька форм свідомого впливу на особистість. Мовленнєвий вплив - це не єдина форма втручання в свідомість чи підсвідомість людини;

- можливі різні рівноцінні форми мовленнєвого впливу.

Перед тим як визначити кінцеву мету мовленнєвого впливу, О.О. Леонтьєв уводить два поняття: «поле значень» i «смислове поле». Під полем значень, притаманних тому чи іншому індивідові розуміє структурування привласненого ним суспільного досвіду. Має на увазі ту «сітку», крізь яку він «бачить» світ й систему категорій, за допомогою якої людина цей світ розчленовує й інтерпретує. При цьому вчений загострює увагу на тому, що теоретично в усіх індивідів, які є членами одного суспільства і говорять однією мовою, 
поля значень мають співпадати, але практично в них є розбіжності, зумовлені соціальними, віковими та іншими чинниками.

У трактовці смислового поля він спирається на визначення смислу - певної характеристики діяльності: відношення мотиву до мети, своєрідного еквівалента значення в конкретній діяльності індивіда, форми існування значення в індивідуальній психіці, завжди опосередкованій системою відношень індивіда до дійсності. Звідси випливає й визначення смислового поля як структури віднесеності значень до виражених у них мотивів, як включеність значень в ієрархію діяльностей індивіда, який завжди пов'язаний 3 дійсністю через смислове поле: сприймання іï завжди зафарбоване його відношенням до неї. «Що ж стосується поля значень, то воно є абстракцією від смислового поля: це - загальні для всіх членів даної спільноти характеристики смислового поля, ніби такі, що «виносяться за дужки» (Леонтьев, 1999: 273).

Вдаючись при тлумаченні мовленнєвого впливу як психологічно самостійного мовленнєвого акту, абстрагуючись від обов’язкової двосторонності будь-якої комунікації, впливу немовними засобами на зразок міміки, інтонації, i вибравши форму впливу через переконання, науковець обгрунтовано визначає мету мовленнєвого впливу як певну організацію діяльності людини, на яку впливають, тобто реципієнта. При впливові на нього «провокується» його поведінка в необхідному суб'єктові впливу (мовцю) напрямку, віднаходяться в системі його діяльності «слабкі місця», виокремлюються чинники, що управляють цією діяльністю й вибірково здійснюється вплив на них. При такому розумінні мовленнєвого впливу сприймання реципієнтом чужої думки не може бути пасивним підкоренням волі іншої людини. Це сприймання передбачає боротьбу i свідому оцінку значимості мотивів, більш-менш свідомий вибір 3 великої кількості можливих варіантів, зауважує О.О. Леонтьєв. Мовленнєвий вплив у такому випадку слугує не для спрощення самого цього вибору, а для полегшення усвідомлення, орієнтування в ситуації, підказки реципієнту відомих підстав для вибору, адже мовленнєвий, як і інший вплив, передусім спрямований на зрушення в системі цінностей реципієнта. Будь-який вплив не може вважатися мовленнєвим, якщо у реципієнта не виник вибір, відсутня боротьба мотивів. 
3 метою досягнення змін у наявних у реципієнта цінностей під впливом комунікатора О.О. Леонтьєв пропонує кілька способів: 1) увести в поле значень реципієнта нові значення; 2) змінити структуру його поля значень, не вводячи в нього нових елементів; 3) безпосередньо впливати на смислове поле.

Перший спосіб передбачає повідомлення реципієнту знань про невідомі йому елементи дійсності, на тлі яких він змінить свою поведінку або в крайньому випадку своє ставлення до цієї дійсності.

Другий спосіб зорієнтований на те, щоб повідомити реципієнтові нову інформацію про вже відомі йому речі, зокрема таку, яка об'єктивно суттєва для розуміння цих речей в їх взаємозв'язку i яка спроможна змінити його уявлення про їх взаємозв'язки i, відповідно, його ставлення до фактів, подій, елементів дійсності. Отже, відбувається мовленнєвий вплив завдяки інформуванню.

Щодо третього способу, то він розрахований на вплив через переконання. Цей спосіб визначається тим, що реципієнт не отримує ніякої об'єктивно нової інформації про елементи поля значень, на його смислове поле впливають безпосередньо, змінюючи спосіб входження елементів поля значень в його діяльність та змінюючи його ставлення до дійсності, не торкаючись його абстрактного знання про неї. Реципієнту повідомляється про те, що він знає, але це знання представляється в іншому ракурсі: відома йому інформація пов'язується 3 новим, ієрархічно складнішим мотивом або «зіштовхуються» мотиви різної «висоти», здійснюється переконання орієнтуватися на більш високий мотив (відтермінувати відпустку, враховуючи інтереси підприємства). Важливим науковим і прикладним аспектом проблеми впливу-переконання О.О. Леонтьєв вважає моделювання комунікатором смислового поля реципієнта для успішного здійснення мовленнєвого втручання. Мовець має уявляти собі смислове поле реципієнта не тільки в момент дії, а й після неї. Мається на увазі, що людині, яка впливає, потрібно уявляти вектори тих змін в смисловому полі реципієнта, яких він має досягти в результаті впливу. При цьому, зауважує науковець, достатньо моделювати лише вузький фрагмент смислового поля, а не ціле поле. Вивчення ролі такого моделювання в процесах масової комунікації він вважав самостійним й надзвичайно важливим науковим завданням, оскільки його успіх і ефективність (а це й 
мас-медіа, й публічні виступи, й освіта, й політика, й психотерапія, й психоконсультування тощо) залежить від адекватного уявлення мовця про те, на кого і як саме він впливає. Проте таких знань комунікатори здебільшого не мають і діють у кращому випадку на інтуїтивному рівні.

Вплив через переконання, як правило, наголошує вчений, поєднується 3 впливом через інформування, хоча 3 теоретичною метою ї доцільно розглядати окремо. Тому зміна смислового поля всерівно можлива лише через значення, незважаючи на те, що вплив через переконання передбачає зміну смислового поля без зміни поля значень, тому що мовленнєвий вплив завжди здійснюється за допомогою мовних та інших суспільно вироблених засобів. У окремих випадках мовленнєвий вплив може доповнюватися не пов'язаними зі значеннями - не домінантними способами впливу (міміка, жестикулювання). Тому, наголошує О.О. Леонтьєв, комунікатор має додатково знати про оптимальне співвідношення смислового поля й відповідних йому значень. Крім того, володіти знанням про правила оптимального перекладу (легкого та адекватного декодування) реципієнтом системи смислів в організовану послідовність значень. Психологічна суть мовленнєвого впливу в тому й полягає, що на основі подвійного (наявного й бажаного) моделювання смислового поля і на основі знань про правила оптимальної трансформації смислового поля в значення мовець кодує бажані зміни в смисловому полі реципієнта у вигляді мовленнєвого повідомлення. Щодо реципієнта, то він у цей час, сприймаючи повідомлення, декодує його та виокремлює 3 нього приховану за зовнішнім планом значень глибинну інформацію, яка зумовлює реальну чи потенційну зміну його діяльності. У зв'язку 3 цим О.О. Леонтьєв особливо відмічає, що правила оптимального кодування аж ніяк не зводяться до перекладу окремих ізольованих смислів у такі ж окремі ізольовані значення. Тут необхідна система кодів, яка перекладає ієрархічну систему смислів у мовленнєву форму. Код «смисл-значення» на рівні слів - це найнижча, найелементарніша ступінь цієї системи. 3 огляду на це вчений наполягає на необхідності володіти мовцю системою мовленнєвих умінь, зокрема вміти об'єктивно доцільним способом виразити в словах свої думки і почуття або вибрати з різних доступних йому 
можливостей мовленнєвого їх вираження найближчу до оптимуму. Проте, зауважує дослідник, для більшості носіїв мови вибір мовних засобів на вищих ієрархічних рівнях не детермінований: мовець не спроможний в адекватній формі виразити те, що він хоче, а тому задовольняється випадковими, приблизними засобами вираження. В мовленнєвому впливові ця нездатність найчастіше сполучується 3 невмінням адекватно моделювати смислове поле реципієнта.

Розвиваючи свої міркування, О.О. Леонтьєв обгрунтовує тришаровість психологічної структури мовленнєвого впливу. По-перше, кодування смислів у значення входить на правах операції в складнішу дію, від інших параметрів якої залежить і конкретне здійснення кодування, наприклад, можна використовувати різної розгорнутості правила кодування залежно від того, яка прогнозована комунікатором ступінь піддатливості реципієнта: можливо, достатньо просто натяку, а можливо, необхідне буде й розгорнуте формулювання.

По-друге, мовленнєвий вплив не є самодостатнім: сама по собі зміна смислового поля реципієнта не є метою мовленнєвої дії; вона (мета) полягає в отриманні якогось іншого результату, наприклад, прохання передати хліб (мовленнєвий вплив) спрямований на те, щоб отримати хліб, а не переконати сусіда по столу, що потрібний хліб. Тому про самостійність мовленнєвої дії або самостійності мовленнєвої діяльності правомірно говорити лише стосовно тієї дії, яка спрямована на досягнення певної зовнішньої мети і включає в себе мовленнєвий вплив як операцію.

По-третє, мовленнєвий вплив містить у собі оптимальне кодування. Таким чином, психологічна структура ніби тришарова (Леонтьев, 1999).

Ще один важливий момент, на якому зосереджує увагу вчений: при не співпаданні цілі й результату дії (іх неузгодженості) можлива ієрархічна перебудова іiі структури: зрушення мотиву на ціль, а відтак мотивом стає саме переконання, а не потреба в кінцевому результаті, опредмеченому в ній; відбувається розгортання операцій у самостійні дії і включення в діяльність нових пізнавальних, а не виконавських дій. Важливим стає спочатку, що сказати, і потім, як сказати, а не сказати щось. Першочерговим інтересом для мовця стає, щзо саме зрозумів реципієнт, як він зрозумів, а не те, щ̧о він зрозумів взагалі. 
Підводячи підсумки своїх міркувань щодо мовленнєвого впливу, О.О. Леонтьєв підкреслює, що він описав цей процес без усіх деталей, а реальний його психологічний механізм значно складніший. Своє головне завдання він убачав у створенні теоретичних передумов і умов для розвитку подальших прикладних експериментальних досліджень мовленнєвого впливу в межах міжособистісної і масової комунікації.

\section{Дискусії}

О.О. Леонтьев не помилився в своїх наукових прогнозах i перспективному баченні соціальної та психологічної значущості цього наукового аспекту психолінгвістики мовленнєвого впливу. Через майже півстоліття 3 того часу, як була представлена науковій громадськості ця модель, вона не тільки не втратила своєї актуальності, а й набула особливої вагомості й неймовірної за своєю прикладною привабливістю поширеності в різних сферах життєдіяльності людини та функціонування суспільства.

Концепція мовленнєвого впливу, як засвідчують результати дискурс аналізу висловлювань фахівців різних мовленнєвоцентрованих професій, широко затребувана в освіті, медицині (слово лікує, слово калічить), психотерапії, психопрофілактиці, психоаналітиці, психоконсультуванні, бізнесі, управлінні, адмініструванні, менеджменті, політології, юриспруденції, масмедіа, соціології, у внутрішній i зовнішній політиці, науці, рекламі, культурі, сім'ї, та інших соціальних сферах суспільства та життєдіяльності людини.

I як нам представляється, питання мовленнєвого впливу вийшло далеко за межі лише психолінгвістичної концепції та моделі: воно, як складова мовленнєвого спілкування, набуло статусу психолінгвістичної теорії, адже містить у своїй структурі логічне узагальнення цієї наукової проблеми й суспільної практики, що грунтується на глибокому проникненні в суть психолінгвістичного явища «вплив» й розкриває його закономірності. Сукупність узагальнених ним складових становлять розділ психолінгвістики, присвячений мовленнєвому спілкуванню, а також $є$ необхідним для опанування майбутніми фахівцями соціономічних, пов'язаних 3 мовленнєвою взаємодією, професій, розуміння ними специфіки їхньої особистісно й соціально центрованої діяльності. 
Psycholinguistic Concept and the Model of Speech Influence...

Будучи ученням про сукупність психолінгвістичних явищ, пов'язаних їз впливом, створена О.О. Леонтьєвим теорія презентує загальні засади мовленнєвого спілкування, систему його поглядів i суджень, 3 яких випливають своєрідні правила, аксіальної (діалогічної) i ретиальної (зокрема масової) комунікативномовленнєвої поведінки суб’єктів контакту.

\section{Висновки}

Найсуттєвіше в психолінгвістичному доробку О.О. Леонтьєва, присвяченому мовленнєвому впливові, - це детальний феноменологічний аналіз мовленнєвого спілкування. Розроблена ним концепція пояснення й доведення грунтується на результатах аналізу походження цього психолінгвістичного феномену в межах історичних форм розвитку спілкування, на глибокому розумінні психологічної природи впливу, на трактуванні його як складової двостороннього процесу, який спричиняє зворотний зв'язок, комунікативно-смислову взаємодію через мовні значення в межах мовленнєвого спілкування як діяльності спілкування.

Представляє значний науковий інтерес для сучасних розвідок 3 психолінгвістики: а) потрактування мовленнєвого впливу як однієї з сторін психологічного змісту спілкування з використанням загальнонаукових понять: «знак», «значення», «смисл», «смислове поле реципієнта» та ін.; б) розмежування таких категорій, як-от: «внутрішне мовлення», «внутрішне програмування» і «внутрішнє промовляння»; в) розкриття як когнітивного аспекту мови - засобу розпредмечення об'єктивної дійсності - процесів виформовування особистісних смислів засобами мовних значень, смислоутворення через мовленнєвий вплив, так i комунікативного аспекту мовних знаків та багатьох інших положень, які в сукупності презентують суть і вектори психолінгвістичного явища «мовленнєвий вплив».

Дуже цікавою є для психолінгвістичної науки представлена О.О. Леонтьєвим теоретична модель мовленнєвого впливу, що відображає смисловий взаємозв'язок і взаємозумовленість комунікатора і реципієнта та семіотичну опосередкованість процесів мовленнєвого спілкування. Навіть перший короткий вступ до розділу «Психолінгвістична модель мовленнєвого впливу» навчального посібника, створеного ним на монографічних матеріалах (Леонтьев, 1999: 271-272) не може не привернути уваги тих, хто професійно 
займається цією проблемою. В ньому чітко сформульовано поняття впливу й визначено його мету, згідно з якою сприймання реципієнтом засобів впливу передбачає боротьбу мотивів, свідому оцінку їх значимості й свідомий вибір 3 ряду можливих, а також зумовлені ним конструктивні зрушення в системі його цінностей.

Не тільки теоретичну, а й практичну важливість цього доробку важко переоцінити. О.О. Леонтьєв запропонував у психолінгвістичній моделі кілька дієвих, науково обгрунтованих, способів мовленнєвого впливу, шляхи і способи втручання в смислове поле реципієнта, розкрив тришаровість психологічної структури впливу, що важливо враховувати, як під час здійснення освітньої роботи з майбутніми фахівцями соціономічних професій, так і у внутрішній і зовнішній мовленнєвій комунікації сьогодення.

Крім того, представлений у «Психології спілкування» О.О. Леонтьєва (1999) аналіз не є тільки теоретичним. Він також спирається на широкий експериментальний матеріал, отриманий в процесі спеціальних досліджень, які здійснювалися як під керівництвом, так і при участі іiі автора.

\section{Література}

Вовк, О.Д. Теоретичні і методичні основи формування комунікативно-когнітивної компетентності майбутніх філологів : автореф. дис. ... д-ра пед. наук : 13.00.04. Черкаси, 2014. 38 с.

Доценко, Е.Л. Психология манипуляции: феномены, механизмы и защита. Москва : ЧеРо, Изд-во МГУ, 1997. 344 с.

Кабаченко, Т.С. Методы психологического воздействия. Москва : Педагогическое общество России, 2000. 544 с.

Ковалев, Г.А. Психологическое воздействие: теория, методология, практика: автореф. дисс. ... д-ра психол. наук : 19.00.01. Москва, 1991. 51 с.

Латынов, В.В. Психологическое воздействие: принципы, механизмы, теории. Психологическое воздействие: Механизмы, стратегии, возможности противодействия / Под ред. А.Л. Журавлева, Н.Д. Павловой. Москва : Изд-во «Институт психологии РАН», 2012. С. 11-12.

Леонтьев, А.А. К психологии речевого воздействия. Материаль IV Bсесоюзного симпозиума по психолингвистике и теории коммуникации. Москва, 1972. C. $28-41$.

Леонтьев, А.А. Психолингвистические проблемы массовой коммуникации. Москва : Наука, 1974. 148 с.

Леонтьев, А.А. Психология общения. Москва : Смысл, 1999. 365 с.

Леонтьев, А.А. Основы психолингвистики. Москва : Смысл, Санкт-Петербург : Лань, 2003. 287 с.

Лахтадир, О.В. Психологічні особливості розвитку комунікативної компетентності майбутніх фахівців з фізичної культури і спорту : автореф. дис. ... канд. психол. наук : 19.00.07. Київ, 2017. 20 с. 
Немеш, О.М. Психологія комунікативної діяльності в інтернет просторі : автореф. дис. ... д-ра психол. наук : 19.00.01. Київ, 2017. 51 с.

Тарасов, Е.Ф. Проблемы теории речевого общения. Вопросы психолингвистики. 2010. Вып. 12. С. 20-27.

Тарасов, Е.Ф. Онтологические предпосылки теории речевого общения. Bопросы психолингвистики. 2017. Вып. 2(32). С. 160-168.

Чалдини, Р. Психология влияния. Санкт-Петербург : Питер, 2010. 336 с.

Bosco, F.M., \& Gabbatore, I. (2017). Theory of mind in recognizing and recovering communicative failures. Applied Psycholinguistics, 38(1), 57-88. doi : 10.1017/ S014271641600004

Gross, E.F. (2004). Adolescent Internet use: What we expect, what teens report. Journal of Applied Developmental Psychology, 25(6), 633-649. doi : 10.1016/j. appdev.2004.09.005

Katherine, Bessière, Sara, Kiesler, Robert, Kraut, \& Bonka, S. Boneva (2008). Effects of internet use and social resources on changes in depression. Information, Communication \& Society, 11(1), 47-70. doi: 10.1080/13691180701858851

Kraut, R., Kiesler, S., Boneva, B., Cummings, J., Helgeson, V., \& Crawford, A. (2002). Internet paradox revisited. Journal of Social Issues, 58(1), 49-74.

Rabab'ah, G. (2016). The effect of communication strategy training on the development of EFL learners' strategic competence and oral communicative ability. Journal of Psycholinguistic Research, 45(3), 625-651. doi: 10.1007/s10936-015-9365-3

Raven, B.H. (1992). A power/interaction model of interpersonal influence: French and Raven thirty years later. Journal of Social Behavior and Personality, 7(2), 217-244.

Schwarzer, R., \& Knoll, N. (2007). Functional roles of social support within the stress and coping process: A theoretical and empirical overview. International Journal of Psychology. 42(4). 243-252. doi: 10.1080/00207590701396641

Seidman, G., Shrout, Patrick E., \& Bolger, N. (2006). Why is enacted social support associated with increased distress? Using simulation to test two possible sources of spurious-ness. Personality and Social Psychology Bulletin, 32, 52-65. doi:10.1177/0146167205279582

Tavakoli, E., \& Davoudi, M. (2017). Willingness to communicate orally: the case of iranian efl learners. Journal of Psycholinguistic Research, 46(6), 1509-1527. doi: 10.1007/s10936-017-9504-0

Valkenburg, Patti M., \& Peter, J. (2009). Social consequences of the Internet for adolescents: A decade of research. Current Directions in Psychological Science, 18(1), 1-5. doi: 10.1111/j.1467-8721.2009.01595.x

Wood, W. (2000). Attitude change: persuasion and social influence. Annual Review of Psychology, 51, 539-570.

\section{References}

Vovk, O.D. (2014). Teoretichni i metodichni osnovi formuvannya komunikativnokognitivnoï kompetentnosti maybutnikh filologiv [Theoretical and methodological foundations of formation the communicative-cognitive competence of future philologists]. Extended abstract of Doctor's thesis. Cherkasi [in Ukrainian].

Dotsenko, E.L. (1997). Psikhologiya manipulyatsii: fenomeny, mekhanizmy i zashchita [Psychology of manipulation: phenomena, mechanisms and defense]. Moscow: CheRo, Izd-vo MGU [in Russian]. 
Kabachenko, T.S. (2000). Metody psikhologicheskogo vozdeystviya [Methods of psychological impact]. Moscow : Pedagogicheskoe obshchestvo Rossii [in Russian].

Kovalev, G.A. (1991). Psikhologicheskoe vozdeystvie: teoriya, metodologiya, praktika [Psychological impact: theory, methodology, practice]. Extended abstract of Doctor's thesis. Moscow [in Russian].

Latynov, V.V. (2012). Psikhologicheskoe vozdeystvie: printsipy, mekhanizmy, teorii [Psychological impact: principles, mechanisms, theories]. Psikhologicheskoe vozdeystvie: Mekhanizmy, strategii, vozmozhnosti protivodeystviya - Psychological Impact: Mechanisms, Strategies, Opportunities of counteraction. A.L. Zhuravleva, N.D. Pavlovoy (Eds.), (pp. 11-12). Moscow : Izd-vo «Institut psikhologii RAN» [in Russian].

Leontyev, A.A. (1972). K psikhologii rechovogo vozdeystviya [To the psychology of speech effects]. Proceedings: IV Vsesoyuznogo simpoziuma po psikholingvistike $i$ teorii kommunikatsii - The Sixth All-Union Symposium on Psycholinguistics and Communication Theory. (pp. 28-41). Moscow [in Russian].

Leontyev, A.A. (1974). Psikholingvisticheskie problemy massovoy kommunikatsii [Psycholinguistic problems of mass communication]. Moscow : Nauka [in Russian].

Leontyev, A.A. (1999). Psikhologiya obshcheniya [Communication psychology]. Moscow : Smysl [in Russian].

Leontyev, A.A. (2003). Osnovy psikholingvistiki [Basics of Psycholinguistics]. Moscow : Smysl, SPb: Lan [in Russian].

Lakhtadir, O.V. (2017). Psikhologichni osoblivosti rozvitku komunikativnoï kompetentnosti maybutnikh fakhivtsiv z fizichnoï kulturi i sportu [Psychological peculiarities of the development of communicative competence of future specialists in physical culture and sports]. Extended abstract of candidate's thesis. Kyiv [in Ukrainian].

Nemesh, O.M. (2017). Psikhologiya komunikativnoï diyalnosti v internet prostori [Psychology of communicative activity in the Internet space]. Extended abstract of Doctor's thesis. Kyiv [in Ukrainian].

Tarasov, E.F. (2010). Problemy teorii rechevogo obshcheniya [Problems of the theory of speech communication]. Voprosy psikholingvistiki - Journal of Psycholinguistic, 12, 20-27 [in Russian].

Tarasov, E.F. (2017). Ontologicheskie predposylki teorii rechevogo obshcheniya [Ontological background of the theory of speech communication]. Voprosy psikholingvistiki - Journal of Psycholinguistic, 2(32), 160-168 [in Russian].

Chaldini, R. (2010). Psikhologiya vliyaniya [Psychology of influence]. SPb: Piter [in Russian].

Bosco, F.M., \& Gabbatore, I. (2017). Theory of mind in recognizing and recovering communicative failures. Applied Psycholinguistics, 38(1), 57-88. doi : 10.1017/ S014271641600004

Gross, E.F. (2004). Adolescent Internet use: What we expect, what teens report. Journal of Applied Developmental Psychology, 25(6), 633-649. doi : 10.1016/j. appdev.2004.09.005

Katherine, Bessière, Sara, Kiesler, Robert, Kraut, \& Bonka, S. Boneva (2008). Effects of internet use and social resources on changes in depression. Information, Communication \& Society, 11(1), 47-70. doi: 10.1080/13691180701858851 
Kraut, R., Kiesler, S., Boneva, B., Cummings, J., Helgeson, V., \& Crawford, A. (2002). Internet paradox revisited. Journal of Social Issues, 58(1), 49-74.

Rabab'ah, G. (2016). The effect of communication strategy training on the development of EFL learners' strategic competence and oral communicative ability. Journal of Psycholinguistic Research, 45(3), 625-651. doi: 10.1007/s10936-015-9365-3

Raven, B.H. (1992). A power/interaction model of interpersonal influence: French and Raven thirty years later. Journal of Social Behavior and Personality, 7(2), 217-244.

Schwarzer, R., \& Knoll, N. (2007). Functional roles of social support within the stress and coping process: A theoretical and empirical overview. International Journal of Psychology. 42(4). 243-252. doi: 10.1080/00207590701396641

Seidman, G., Shrout, Patrick E., \& Bolger, N. (2006). Why is enacted social support associated with increased distress? Using simulation to test two possible sources of spurious-ness. Personality and Social Psychology Bulletin, 32, 52-65. doi:10.1177/0146167205279582

Tavakoli, E., \& Davoudi, M. (2017). Willingness to communicate orally: the case of iranian efl learners. Journal of Psycholinguistic Research, 46(6), 1509-1527. doi: 10.1007/s10936-017-9504-0

Valkenburg, Patti M., \& Peter, J. (2009). Social consequences of the Internet for adolescents: A decade of research. Current Directions in Psychological Science, 18(1), 1-5. doi: 10.1111/j.1467-8721.2009.01595.x

Wood, W. (2000). Attitude change: persuasion and social influence. Annual Review of Psychology, 51, 539-570.

\section{АНОТАЦІЯ}

У статті розкриваються основні положення концепції мовленнєвого впливу та описується його теоретична модель, які розроблені відомим психолінгвістом XX століття О.О. Леонтьєвим. Основні ідеї цієї концепції експліковані в межах проблематики мовленнєвого спілкування та зумовлених цим вербальним актом процесів говоріння комунікатора (мовця) й аудіювання реципієнта (-ів). Мовленнєвий вплив розглядається дослідником цієї проблеми на рівні внутрішніх $і$ зовнішніх етапів породження комунікативно-мовленнєвих процесів мовця і реципієнта. Саме тому О.О. Леонтьєв велику увагу в цій концепції приділяє аналізу таких психолінгвістичних явищ, як: "значення», "смисл", "смислове поле реципієнта», «знак», "внутрішнє мовлення», "внутрішнє програмування», "мовленнєва дія» та ін. У статті розкриваються такі аспекти: а) встановлена О.О. Леонтьєвим еволюція форм спілкування ma його психологічна й семіотична опосередкованість; б) виокремлені ним етапи історичного становлення діяльності спілкування,зокрема його прикінцевого етапу - мовленнєвого впливу, який стає професійною діяльністю, мотивованою «зсередини себе»; в) розмежовані дослідником поняття "мовлення» i "мовленнєва діяльність»; г) визначене поняття "спілкування» та його різновиди; ґ) пов'язаний з орієнтацією - критерієм мовленнєвого спілкування - мовленнєвий 
вплив, який номінується як один з аспектів психологічного змісту спілкування; д) схарактеризований за трьома параметрами феномен знака і застосовані при його інтерпретації важливі для глибокого розуміння мовленнєвого впливу два шляхи наукового аналізу через процеси розуміння (перехід від знака до думки) і через об'єктивацію суб'єктивного комунікативного наміру (перехід від думки до знаку) та інші важливі положення запропонованої концепції. В змісті цього рукопису також описується психолінгвістична модель мовленнєвого впливу, який, на думку ії автора, має статуси або психологічні дії, або постає як самостійна діяльність з власним мотивом, має зворотний зв'язок, набуває різних форм втручання в свідомість $і$ підсвідомість особистості тощо; репрезентуються способи досягнення змін у наявних у реципієнтів цінностях під впливом змісту мовлення комунікатора; обгрунтовується тришаровість психолінгвістичної структури мовленнєвого впливу. В дискусійному розділі статmі пропонується науковий доробок О.О. Леонтьєва щодо мовленнєвого впливу вважати психолінгвістичною теорією, враховуючи його теоретичну й практичну значущість для сучасної науки та комунікативної практики.

Ключові слова: мовленнєвий вплив; значення; смисл; смислове поле реципієнта; знак; поле значень.

\section{Максименко Ксения, Калмыков Георгий. Психолингвистическая концепция и модель речевого воздействия А.А.Леонтьева и ее значение для актуализации современных проблем общения}

\section{АННОТАЦИЯ}

В статье раскрываются основные положения концепции речевого воздействия и описывается его теоретическая модель, разработанная известным психолингвистом ХХ века А.А. Леонтьевым. Основные идеи этой концепции эксплицированы в рамках проблематики речевого общения и обусловленных этим вербальным актом процессов говорения коммуникатора (говорящего) и аудирования реципиента(ов). Речевое воздействие рассматривается исследователем этой проблемы на уровне внутренних и внешних этапов порождения коммуникативноречевых прочессов говорящего и реципиента. Именно поэтому А.А. Леонтьев в этой концепции большое внимание уделяет анализу таких психолингвистических явлений, как "значение», "смысл», "смысловое поле реципиента», "знак», "внутренняя речь", "внутреннее программирование», "речевое действие» и др. В статье раскрываются следующие аспекты: а) установленная А.А. Леонтьевым эволюция форм общения и его психологическая и семиотическая опосредованность; б) выделенные ним этапы становления деятельности общения, в 
Psycholinguistic Concept and the Model of Speech Influence...

частности его конечного этапа - речевого воздействия, которое становится профессиональной деятельностью, мотивированной "изнутри себя»; в) разграниченные исследователем понятия "речь" и "речевая деятельность»; г) срормулированное понятие "общение» и его разновидности; д) связанное с ориентацией - критерием речевого общения - речевое воздействие, номинированное как один из аспектов психологического содержания общения; ж) охарактеризованный по трем параметрам феномен знака и используемые при его интерпретации важные для глубокого понимания речевого воздействия два пути научного анализа: через процессы понимания (переход от знака к мысли) и через объективацию субъективного коммуникативного намерения (переход от мысли к знаку) и другие важные положения предложенной концепции. В содержании этой рукописи также описывается психолингвистическая модель речевого воздействия, которая, по мнению ее автора, имеет статус или психологического действия, или самостоятельной деятельности с собственным мотивом, имеет обратную связь, приобретает различные формы вмешательства в сознание и подсознание личности и т.д.; предлагаются способы достижения изменений в имеющихся у реципиентов ценностях под влиянием содержания речи коммуникатора; обосновуется трехслойность психологчческой структуры речевого воздействия. В дискуссионном разделе статьи предлагается научный потенциал А.А. Леонтьева по речевому воздействию считать психолингвистической теорией, учитывая его теоретическую и практическую значимость для современной науки и коммуникативной практики.

Ключевые слова: речевое воздействие, значения, смысл, смысловое поле реципиента, знак, поле значений. 